\title{
Rancang Bangun Tanggap Darurat Bencana Berbasis Sistem Informasi Geografis (SIG)
}

\section{Design of Disaster Emergency Response Based on Geographical Information System}

Husmul Beze*, Dawamul Arifin, Suriani

Jurusan Manajemen Pertanian, Politeknik Pertanian Negeri Samarinda, Indonesia

${ }^{*}$ Corresponding author: husmul.politani@gmail.com

\begin{abstract}
ABSTRAK
Bencana alam masih menjadi masalah di Indonesia, khususnya Samarinda. Banjir dan kebakaran merupakan masalah utama di Kota Samarinda. Untuk mengantisipasinya perlu sebuah perencanaan penanggulangan untuk mengurangi resiko. Tanggap darurat adalah serangkaian kegiatan yang dilakukan dengan segera pada saat kejadian bencana untuk menangani dampak buruk yang ditimbulkan. Oleh karena itu dilakukan penelitian ini yaitu membuat prototype sistem informasi tanggap darurat bencana berbasis web tentang lokasi posko bencana dan memberikan informasi terkait logistik posko kepada masyarakat. Metode yang digunakan dalam pembuatan aplikasi yaitu metode SDLC (System Development Life Cycle) yang dikembangkan oleh James A. O'Brien dan George M. Marakas. Hasil Penelitian ini diharapkan adanya web tanggap bencana yang memiliki fitur pencarian lokasi posko dan fitur lainnya. Berdasarkan uji coba aplikasi dengan dengan metode black box terhadap 31 responden, sekitar 50.8\% menyatakan fitur aplikasi yang kembangkan sudah memenuhi harapan dalam penanggulangan bencana.
\end{abstract}

Kata kunci: sistem informasi geografis, posko bencana, tanggap darurat bencana

\section{ABSTRACT}

Natural disasters are still a problem in Indonesia, especially Samarinda. Flood and fired are major problem in Samarinda City. To anticipate this, it is necessary to plan countermeasures to reduce risks. Emergency response is a series of activities carried out immediately at the time of a disaster to deal with the bad impacts that may be caused. Therefore, this research was conducted, namely making a web-based prototype of the disaster emergency response information system about the location of the disaster post and providing information related to the logistics of the post to the community. The method used in making the application is the SDLC (System Development Life Cycle) method developed by James A. O'Brien and George M. Marakas. The results of this study are expected to have a disaster response web that features a search for post locations and other features. Based on application trials with the black box method of 31 respondents, around $50.8 \%$ stated that the application features developed had met expectations in disaster management.

Keywords: laravel, php, geographic information system, disaster post, disaster response

\section{PENDAHULUAN}

Ibu Kota Provinsi Kalimantan Timur, kota Samarinda mengalami perkembangan kegiatan dan fungsi perkotaan, bahkan menjadi salah satu pusat pertumbuhan ekonomi sekaligus pusat kegiatan bagi kawasan Timur Pulau Kalimantan (Kalimantan Timur, 2008).

Sebagai ibukota derasnya urbanisasi dan migrasi dari daerah lain telah memacu perkembangan pemukiman yang cenderung menyimpang dari konsep pembangunan yang berkelanjutan. Banyaknya kawasankawasan rendah (rawa, danau) yang semula berfungsi sebagai tempat penampung air serta bantaran sungai yang berubah menjadi pemukiman, ditambah dengan kebiasaan masyarakat yang membuang sampah ke sungai makin memperburuk kondisi ini (Nur, 2016).

Berkurangnya lahan-lahan dapat mengurangi kualitas dan kuantitas infiltrasi air hujan yang jatuh selama musim hujan. Langsung maupun tidak langsung, cepat atau lambat, pengaruh perubahan siklus air ini berdampak pada kondisi lingkungan dan kenyamanan tinggal khususnya di daerah perkotaan. Dari hal tersebut bencana banjir sulit dihindari apabila tidak diatasi baik jangka pendek maupun jangka panjang tidak 
menutup kemungkinan banjir dapat menggenangi seluruh Samarinda tidak terkecuali daerah yang selama ini disebut daerah bebas banjir (Nur, 2016) .

Bencana adalah peristiwa atau rangkaian peristiwa yang mengancam dan mengganggu kehidupan dan penghidupan masyarakat yang disebabkan, oleh faktor alam maupun faktor manusia sehingga mengakibatkan timbulnya korban jiwa manusia, kerusakan lingkungan, kerugian harta benda dan dampak psikologis (UU, 2007). Jenis-jenis dari bencana alam seperti banjir, kebakaran, tanah lonsor, angin topan, tsunami.

Kebakaran merupakan bencana yang paling sering dihadapi dan biasa digolongkan sebagai bencana alam atau bencana yang disebabkan oleh manusia. Bahaya kebakaran dapat terjadi setiap saat, karena banyak peluang yang dapat memicu terjadinya kebakaran. Definisi umum kebakaran adalah suatu peristiwa terjadinya nyala api yang tidak dikehendaki, sedangkan definisi khususnya adalah suatu peristiwa oksidasi antara tiga unsur penyebab kebakaran yaitu bahan padat, bahan cair, dan bahan gas (Zamiati, 2014).

Ketika terjadi suatu bencana alam manusia hanya mampu meminimalisirnya dan melakukan planning tindakan pengurangan resiko pra bencana. Tanggap darurat adalah serangkaian kegiatan yang dilakukan dengan segera pada saat kejadian bencana untuk menangani dampak buruk yang ditimbulkan, yang meliputi kegiatan penyelamatan dan evakuasi korban, harta benda, pemenuhan kebutuhan dasar, perlindungan, penanganan pengungsi, penyelamatan serta pemulihan sarana dan prasarana (Badan Nasional Penanggulangan Bencana, 2013).

Pengurangan risiko bencana dilakukan dengan mempertimbangkan aspek berkelanjutan dan partisipasi dari semua pihak terkait yaitu di dalamnya harus adanya peran masyrakat dalam mitigasi bencana. Upaya ini dilakukan dengan komitmen yang kuat dan mengedepankan tindakan-tindakan yang harus diprioritaskan (Supriyono \& Dkk, 2018).

Teknologi berkembang dengan sangat pesat, dan teknologi sangat penting untuk kehidupan manusia jaman sekarang, karena teknologi adalah salah satu penunjang perkembangan manusia. Contoh perkembangan teknologi misalnya dibidang komunikasi, di jaman dulu masyarakat menggunakan surat, telegram atau alat tradisional lain untuk bisa berkomunikasi dengan yang lain. Setelah terjadi perkembangan teknologi mulai muncul handphone sebagai alat komunikasi yang canggih dan lebih efisien yang sangat memudahkan komunikasi jarak jauh maupun dekat. Adanya teknologi dapat membut pekerjaan menjadi lebih efisien dan efektif. Setiap pemakai teknologi dapat mencari suatu informasi yang diingikan.

Salah satu teknologi informasi yang berkembang juga adalah sistem informasi geografis dimana sistem informasi geografis (SIG) adalah suatu sistem informasi yang dirancang untuk bekerja dengan data yang bereferensi spasial atau berkoordinat geografi atau dengan kata lain suatu SIG adalah suatu sistem basis data dengan kemampuan khusus untuk menangani data yang bereferensi keruangan (spasial) bersamaan dengan seperangkat operasi kerja. Disamping itu, SIG juga dapat menggabungkan data, mengatur data, dan melakukan analisis data yang akhirnya akan menghasilkan keluaran yang dapat dijadikan acuan dalam pengambilan keputusan pada masalah yang berhubungan dengan geografi (Prahasta, 2002).

Beze dkk (2018) menguatkan bahwa sistem informasi geografis bisa dijadikan solusi dalam masalah sosial dan teknis. Oleh karena itu maka perlu dibangun suatu sistem informasi yaitu "RANCANG BANGUN TANGGAP DARURAT BENCANA BERBASIS SISTEM INFORMASI GEOGRAFIS (SIG)"

Berdasarkan latar belakang di atas, maka rumusan masalah dari penelitian ini adalah "Bagaimana membangun prototype sistem informasi tanggap darurat bencana?" Batasan masalah dari penelitian ini adalah:

1. Pembuatan peta dalam aplikasi ini menggunakan API dari Leaflet java script.

2. Data yang disajikan berupa data spasial dan atribut yang ditampilkan dalam bentuk peta pada sebuah web.

3. Posko bencana yang ditampilkan adalah posko banjir dan kebakaran.

4. Kegiatan tanggap darurat bencana hanya pada tahap menampilkan lokasi peta posko dan logistik korban bencana.s 
5. Pembuatan sistem berbasis web ini menggunakan framework laravel.

Tujuan penelitian ini adalah untuk membuat prototype sistem informasi tanggap darurat bencana berbasis web tentang lokasi posko bencana dan memberikan informasi terkait logistik posko kepada masyarakat.

Hasil yang diharapkan adalah adanya web pencarian lokasi posko dan memudahkan untuk memberikan informasi kepada masyarakat tentang apa saja yang dibutuhkan oleh korban setelah bencana terjadi.

\section{METODE PENELITIAN}

\subsection{Waktu dan Tempat Penelitian}

Penelitian ini dilaksanakan di Kota Samarinda Kalimantan Timur sebagai tempat yang akan diteliti. Pembuatan dan pengembangan sistem dilakukan di Laboratorium Program Studi Teknologi Rekayasa Perangkat Lunak (TRPL). Penelitian ini membutuhkan waktu selama 6 bulan yaitu bulan oktober 2019 - maret 2020 meliputi penyusunan proposal, pengambilan data, pembuatan aplikasi, dan peyusunan laporan.

\subsection{Alat Dan Bahan}

Pengembangan sistem informasi geografis ini menggunakan alat dan bahan sebagai berikut:

a. Alat

1. 1 unit Laptop untuk membuka software yang digunakan dalam pembuatan web.

2. HP Oppo A39 digunakan sebagai gps pengambilan titik dan dokumentasi lapangan.

3. Garmin digunakan sebagai gps pengambilan titik.

4. Alat tulis digunakan untuk mencatat segala informasi yang dibutuhkan.

5. Printer digunakan untuk mencetak proposal dan skripsi.

6. Leaflet Java Script API berfungsi untuk menampilkan peta pada aplikasi.

7. Aplikasi Quantum GIS digunakan untuk memasukkan titik posko.

8. Atom digunakan untuk text editor.

9. Xampp berfungsi sebagai server.

\section{b. Bahan}

a. Data Spasial

1) Peta Kota Samarinda

b. Data Non Spasial
1) Data Posko

2) Data Logistik

3) Data Bencana

c. Framework Laravel

\subsection{Prosedur Penelitian}

Penulisan skripsi ini menggunakan metode SDLC (System Development Life Cycle) yang dikembangkan oleh James $A$. O'Brien dan George M. Marakas, dalam perancangan sistem yang digunakan untuk menggambarkan beberapa tahapan dalam proses pengembangan. Diagram alir penelitian ini selengkapnya bisa dilihat pada gambar 5 Tahapan prosedur penelitian dengan (SDLC).

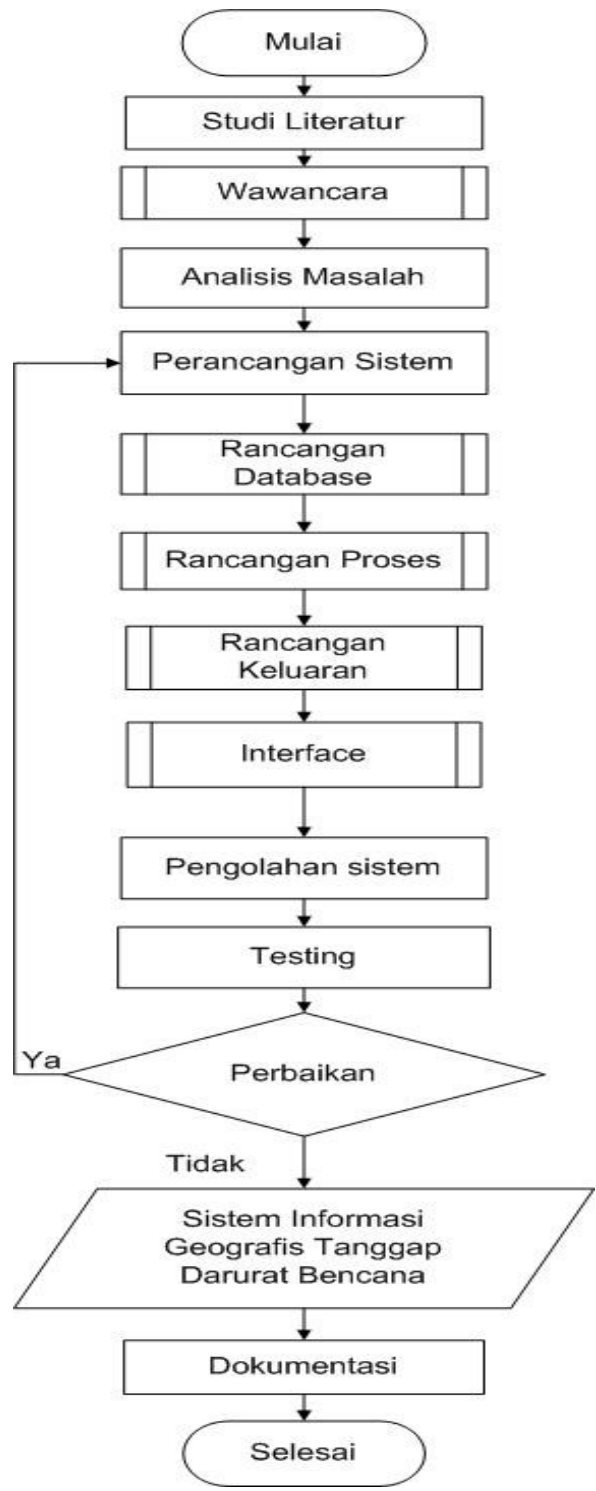

Gambar 1. Flowchart Prosedur Penelitian 
Berikut adalah penjelasan tahapan prosedur penelitian:

\section{Studi Literatur}

a. Studi Pustaka

Pada tahap ini dilakukan studi literatur tentang pengembangan SIG berbasis WEB. Mengambil bahan referensi seperti jurnal dan beberapa buku-buku yang terkait dengan penelitian.

b. Wawancara

Wawancara yang dilakukan kepada Kepala Badan Penanggulangan Bencana Daerah (BPBD) Kalimantan Timur guna mengetahui prosedur serta kegiatan pengolahan data yang dilakukan sehingga dapat memberikan informasi dan data yang bersangkutan dengan penelitian.

\section{Analisis Masalah}

Pada tahap ini dilakukan proses analisa bahwa sistem informasi tanggap bencana banjir dan kebakaran di Kota Samarinda.

\section{Perancangan Sistem}

a. Interface

Ada 7 rancangan (mockup) yang dirancang dalam tampilan antar muka sistem ini yaitu halaman admin, daftar posko, admin poko, superadmin, halaman peta, input data posko dan input data posko spasial.

Untuk tampilan pengunjung ada 5 menu yaitu: Beranda, Peta Posko Bencana, pendaftaran Posko, Login dan Kontak.
Tampilan daftar posko dapat dilihat pada gambar 2.

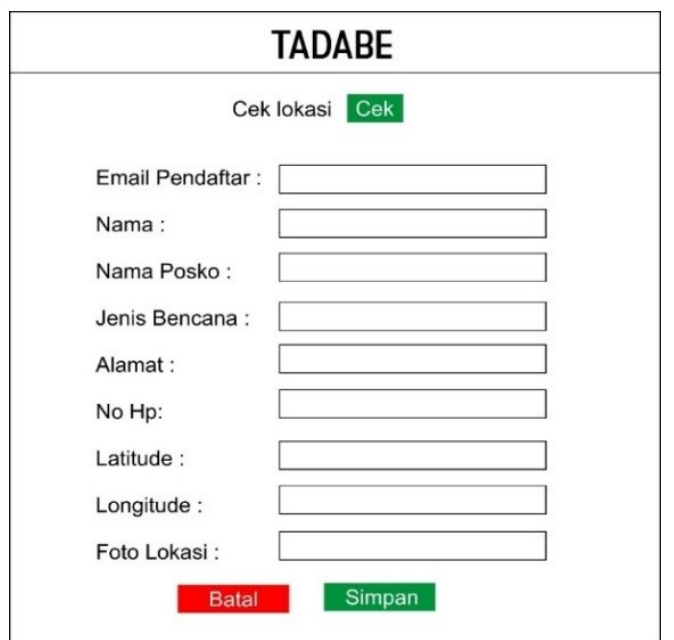

Gambar 2. Tampilan Pendaftaran Posko

Tampilan halaman admin posko ada 5 menu yaitu: Beranda, Data posko, peta Posko dan Logout.

b. Rancangan Proses

1) Data flow diagram level 0

Diagram level 0 pada sistem yang akan dibuat ini menggambarkan proses aliran data secara umum, dimana proses sistem webgis sistem informasi posko terdapat sumber serta tujuan dari yang akan di proses secara rini hingga dapat menggambarkan aliran data yang akan di proses secara rinci hingga dapat menggambarkan aliran data yang akan diproses, diagram level 0 dapat dilihat pada gambar 3 .

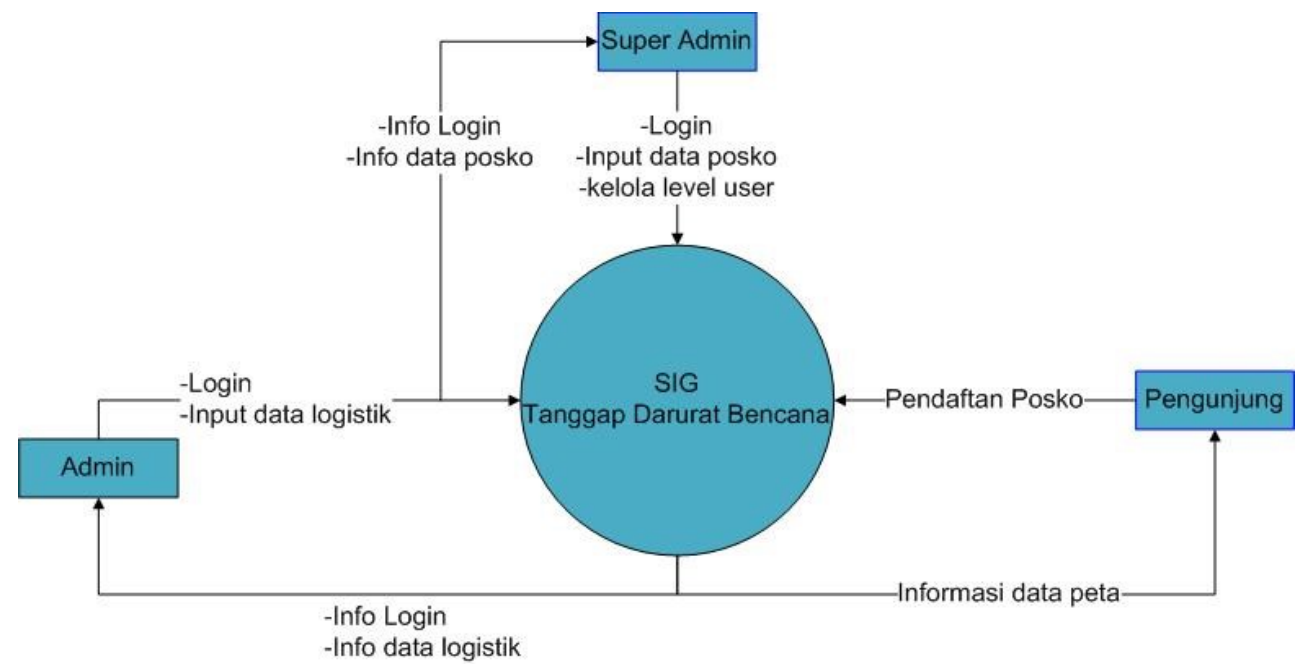

Gambar 1. DFD level 0 
c. Rancangan Keluaran

1) Tampilan peta spasial

2) Tampilan data non spasial

3) Data berupa PopUp

d. Rancangan Database

Dalam rancangan desain database ini akan di buat beberapa desain tabel dan relasi antar tabel. Pada sistem informasi ini terdapat 3 tabel yaitu :

1) Tabel Posko

Tabel posko terdiri dari kolom id tipe data integer (20) dengan keterangan Primary_key, nama_posko tipe data varchar (30), email_pendaftar tipe data varchar (20), alamat tipe data varchar (50), jenis_bencana tipe data varchar (20), jumlah_logistik tipe data integer (20), dan keterangan tipe data varchar (20). Tabel posko dapat dilihat pada tabel 1.

Tabel 1. Tabel Posko

\begin{tabular}{llc}
\hline Nama Field & Tipe data & Keterangan \\
\hline Id & INTEGER $(20)$ & PrimaryKey \\
nama_posko & $\operatorname{VARCHAR}(30)$ & \\
email_pendaftar & $\operatorname{VARCHAR}(20)$ & \\
Alamat & $\operatorname{VARCHAR}(50)$ & \\
jenis_bencana & $\operatorname{VARCHAR}(20)$ & \\
jumlah_Logistik & INTEGER (20) \\
Keterangan & $\operatorname{VARCHAR}(20)$ & \\
\hline
\end{tabular}

1) Tabel Daftar Posko

Tabel daftar posko terdiri dari id tipe data integer (20) dengan keterangan primary_key, email tipe data varchar (30), nama tipe data enum ('P','L'), nama_posko tipe data varchar (20), jenis_bencana tipe data varchar (20), alamat tipe data varchar (20), no hp tipe data integer (13), latitude tipe data varchar (20), longitude tipe data varchar (20), foto tipe data varchar (20). Tabel daftar posko dapat dilihat pada tabel 2 .

Tabel 2. Tabel Daftar Posko

\begin{tabular}{|c|c|c|}
\hline Nama Field & Tipe Data & Keterangan \\
\hline Id & INTEGER (20) & PrimaryKey \\
\hline Email & $\operatorname{VARCHAR(30)}$ & \\
\hline Nama & ENUM('P','L') & \\
\hline Nama_Posko & $\operatorname{VARCHAR}(20)$ & \\
\hline Jenis Bencana & $\operatorname{VARCHAR}(20)$ & \\
\hline Alamat & $\operatorname{VARCHAR}(20)$ & \\
\hline No_hp & $\operatorname{VARCHAR}(13)$ & \\
\hline Latitude & $\operatorname{VARCHAR}(20)$ & \\
\hline Longitude & $\operatorname{VARCHAR(20)}$ & \\
\hline Foto & $\operatorname{VARCHAR}(20)$ & \\
\hline
\end{tabular}

2) Tabel Logistik Posko

Tabel logistik terdiri dari id tipe data integer (20) keterangan primary_key, email_pendaftar tipe data varchar (30), id_posko tipe data integer (20) dengan keterangan foreign_key, satuan tipe data varchar (20), jenis_barang tipe data varchar (20), jumlah tipe data varchar (20), tanggal_masuk date. Tabel logistik dapat dilihat pada tabel 3 .

Tabel 3. Tabel Logistik Posko

\begin{tabular}{lll}
\hline Nama Field & Tipe Data & Keterangan \\
\hline Id & INTEGER $(20)$ & PrimaryKey \\
Email_Pendaftar & VARCHAR(30) & \\
Id_posko & INTEGER (20) & Foreign Key \\
Satuan & VARCHAR(20) & \\
Jenis_barang & VARCHAR(20) & \\
Jumlah & VARCHAR(20) & \\
Tanggal_Masuk & DATE & \\
\hline
\end{tabular}

\section{Pengolahan Sistem}

Pada tahap ini dilakukan proses instalasi dan pengerjaan WebGis yang dibutuhkan, antara lain:
a. Xampp
b. Quantum GIS
c. Laravel
d. Leaflet Javascript
e. Atom
f. Pembuatan website
g. Pengujian internal
h. Pengujian oleh user

\section{Pengujian (Testing)}

Testing adalah pengujian yang dilakukan untuk mengamati hasil eksekusi melalui data uji dan memeriksa fungsional dari perangkat lunak apakah sistem berjalan dengan baik atau tidak, jika ada masalah pada sistem maka akan dilakukan perbaikan fungsi sistem.

\section{Sistem Informasi Geografis Tanggap Darurat Bencana}

Pada tahap ini proses penulisan skripsi yang ditulis dan diterbitkan untuk memaparkan hasil penelitian atau pengkajian yang telah dilakukan.

\section{Dokumentasi}

Pada tahap ini dilakukan pendokumentasian tentang fungsi-fungsi dari fitur yang ada pada prototipe aplikasi sistem informasi tanggap bencana. 


\section{HASIL DAN PEMBAHASAN}

\subsection{Hasil}

\section{Masukan / Input}

Pada pengembangan sistem terdapat beberapa tampilan masukan (input) yang terdiri dari:

a. Halaman input register

Halaman registrasi merupakan halaman yang ditujukan pada pengunjung yang ingin mendaftarkan posko sebelum melakukan login.

b. Halaman Input login

Halaman login merupakan halaman yang ditujukan untuk admin posko dan super admin.

c. Halaman tambah data posko

Setelah pengunjung melakukan registrasi maka akan diarahkan ke halaman daftar posko. Pada halaman daftar posko pengunjung harus mengisi nama posko, jenis bencana, alamat, latitude, longitude, dan foto lokasi.

d. Halaman tambah data posko

Setelah pengunjung melakukan pengisian di form daftar posko maka admin akan membuatkan titik posko sesuai dengan informasi yang sudah pengunjung isikan. Pada halaman posko admin akan mengisi id posko, nama posko, email pendaftar, alamat, jenis bencana,jumlah logistik.

e. Halaman tambah data logistik

Setelah admin membuatkan posko untuk pengunjung maka status pengunjung tersebut akan berubah menjadi admin posko. Lalu admin posko akan mengisikan data logistik sesuai dengan posko yang sudah pengunjung daftarkan. Pada halaman data logistic admin posko harus mengisi jenis barang, satuan, jumlah dan tanggal masuk.

\section{Proses}

Dalam aplikais ini ada tiga pengguna yang bisa mengakses aplikasi yaitu super admin, admin posko dan pengunjung. Aliran proses RANCANG BANGUN TANGGAP DARURAT BENCANA BERBASIS SISTEM INFORMASI GEOGRAFIS (SIG) bisa dilihat pada diagram konteks berikut ini:

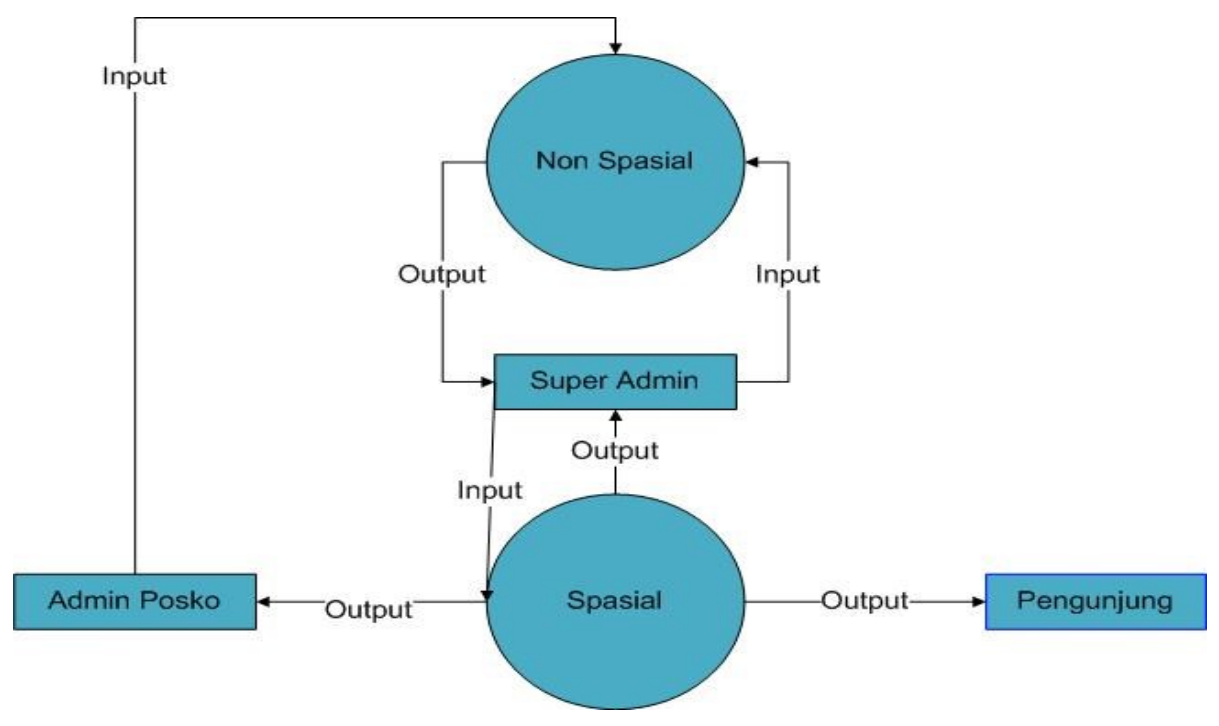

Gambar 4. Proses DFD level 1

\section{Tampilan keluaran/Output}

Tampilan keluaran/output terdapat beberapa tingkatan user akses yang terdiri dari pengunjung, admin dan operator.

1. Tampilan output pengunjung terdapat beberapa halaman menu yang terdiri dari:

1) Halaman beranda pengunjung

Halaman beranda pengunjung adalah halaman yang dibuat untuk umum dan dapat diakses oleh semua pihak.

\section{Halaman pengunjung posko}

Halaman pengunjung posko merupakan halaman yang ditampilkan dalam bentuk peta posko, peta dapat menampilkan pop up yang berupa informasi. ada 2 marker titik warna yang menjelaskan status posko yaitu:

a) hijau = Logistik terpenuhi

b) Merah $=$ Logistik Belum terpenuhi 


\section{Dalam tampilan peta terdapat menu menonaktfikan hasil digitasi berupa titik zoom in, zoom out dan menu peta merupakan menu yang mangaktifkan dan marker.}

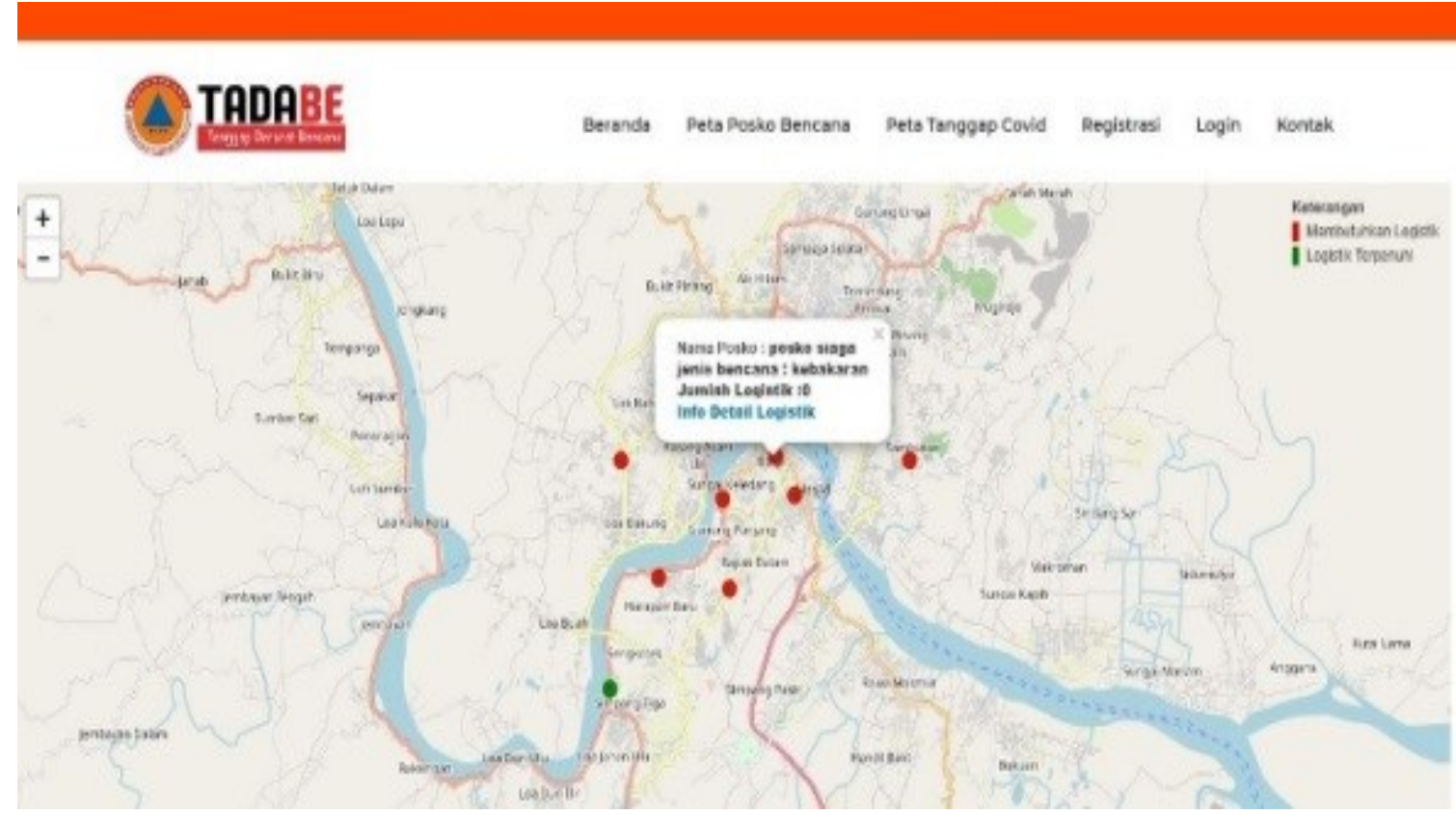

Gambar 5. Halaman Peta Posko Pengunjung

2. Tampilan output admin posko terdapat beberapa halaman menu yang terdiri dari :
a. Menu beranda admin
c. Menu data posko
d. Menu Peta Posko
e. Menu logout admin

3. Tampilan output super admin terdapat beberapa halaman menu yang terdiri dari :

b. Menu beranda admin

c. Menu masterdata : Pendaftar posko, data posko, data logistik, data user.

d. Menu Laporan

e. Menu Peta Posko

f. Menu logout super admin

\section{Basisdata}

Langkah pertama dalam membangun aplikasi adalah melakukan instalasi aplikasi server yaitu menggunakan xampp control panel yang di install pada browser Google Crome. Setelah selesai melakukan instalasi kemudian jalankan aplikasi xampp control panel. Pada sistem yang telah dibangun database yang didalamnya berisi empat tabel yaitu tabel posko, tabel daftar posko, tabel logistik dan tabel user. Berikut adalah hasil dari pembuatan tabel dalam webgis tanggap darurat bencana.
a. Tabel Posko
Tabel posko terdiri dari beberapa kolom yaitu: id, nama posko, email pendaftar, alamat, jenis bencana, jumlah logistik, keterangan.
b. Tabel Daftar Posko
Tabel posko terdiri dari beberapa kolom yaitu: id, email, nama, nama posko, jenis bencana, alamat, nomor hp, latitude, longitude, foto lokasi
c. Tabel Logistik
Tabel posko terdiri dari beberapa kolom yaitu: id, email pendaftar, id posko jenis barang, satuan, jumlah, tanggal masuk.

d. Tabel User

Tabel posko terdiri dari beberapa kolom yaitu: id, nama, email, email verified, password, admin. 

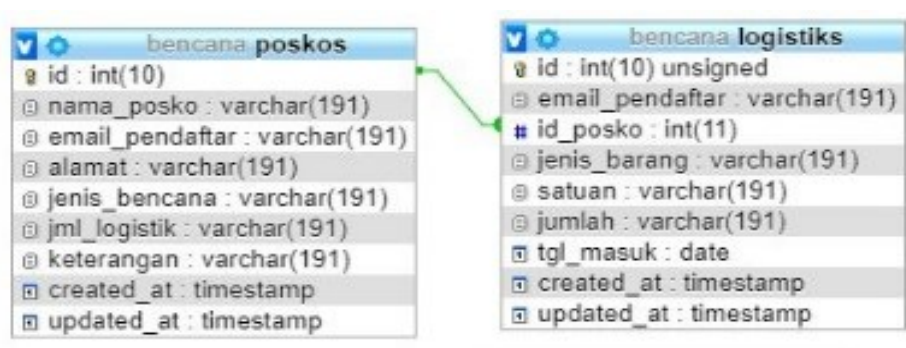

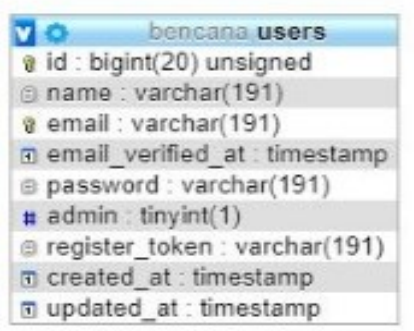

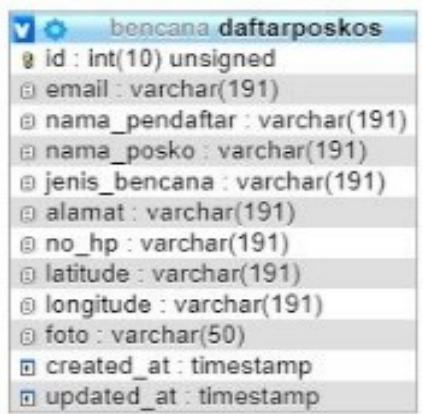

q updated at : timestamp

\section{Gambar 6. Rancangan Fisik Basisdata}

\section{B. Pembahasan}

Sistem yang dikembangkan dalam aplikasi ini memberikan kemudahan dalam:

a. Menemukan informasi posko bencana dan logistik yang tersedia pada posko.

b. Melakukan pendaftaran posko pada sistem dan menginput data logistik yang ada pada posko pendaftar.

c. Mempermudah Bagian admin dalam pelaporan titik posko bencana.
1. Uji Coba Aplikasi

a. Pada hasil uji error coding di lakukan pengecekan dengan cara mencoba setiap fitur di aplikasi, tidak di temukan error pada uji aplikasi yang di jalankan pada server localhost.

b. Pada uji aplikasi di tanyakan 4 pertanyaan kepada 31 responden.

Tabel 4. Tabel Uji Blackbox

\begin{tabular}{|c|c|c|c|}
\hline No & Kelas Uji & Butir Uji & Hasil \\
\hline \multirow[t]{3}{*}{1} & Login \& Logout & $\begin{array}{l}\text { Memasukkan nama pengguna dan kata } \\
\text { sandi }\end{array}$ & Mudah Dipahami \\
\hline & & Membuat akun admin posko & Mudah Dipahami \\
\hline & & Membuat akun super admin & Mudah Dipahami \\
\hline \multirow[t]{3}{*}{2} & Melihat kondisi posko & Input data posko & Mudah Dipahami \\
\hline & Oleh super admin & Edit data posko & Mudah Dipahami \\
\hline & & Hapus data posko & Mudah Dipahami \\
\hline \multirow[t]{3}{*}{3} & Melihat kondisi logistik & Input data logistik & Mudah Dipahami \\
\hline & Oleh super admin & Edit data logistic & Mudah Dipahami \\
\hline & & Hapus data logistik & Mudah Dipahami \\
\hline \multirow[t]{3}{*}{4} & Melihat pendaftar posko & Input data pendaftar posko & Mudah Dipahami \\
\hline & Oleh super admin & Edit data pendaftar posko & Mudah Dipahami \\
\hline & & Hapus data pendaftar posko & Mudah Dipahami \\
\hline \multirow[t]{3}{*}{5} & Pendaftaran Posko oleh & Cek lokasi & Mudah Dipahami \\
\hline & pengunjung & Input data posko & Mudah Dipahami \\
\hline & & Notifikasi ke super admin via whatsapp & Mudah Dipahami \\
\hline \multirow[t]{3}{*}{6} & Melihat Data Logistik oleh & Input data logistik & Mudah Dipahami \\
\hline & (Admin Posko) & Edit data logistik & Mudah Dipahami \\
\hline & & Hapus data logistik & Mudah Dipahami \\
\hline 7 & Melihat halaman peta posko & Dapat menampilkan pop up detail posko & Mudah Dipahami \\
\hline
\end{tabular}


Aplikasi tanggap darurat bencana yang telah dibuat kemudian diujicobakan kepada user. Secara keseluruhan responden uji coba aplikasi berjumlah 31 orang diantaranya terdapat mahasiwa, pekerja swasta,

masyarakat, serta staf BNPB. Hasil uji responden menyatakan bahwa sebanyak $50.8 \%$ responden sangat mudah dan memahami dalam penggunaan fitur yang dikembangkan system.

\section{KESIMPULAN}

Berdasarkan dari hasil tujuan dan analisis yang telah dilakukan diperoleh kesimpulan sebagai berikut :

1. Dengan sistem informasi yang dibuat dapat mempermudah pemakai dalam mendapatkan informasi terkait posko bencana.

2. Aplikasi RANCANG BANGUN TANGGAP DARURAT BENCANA BERBASIS SISTEM INFORMASI GEOGRAFIS (SIG) mampu menampilkan peta posko bencana.

3. Aplikasi dapat menampilkan data berupa informasi status kebutuhan logistik di dalam peta.

4. Terdapat fitur agar orang lain dapat mendaftarkan posko.

5. Aplikasi yang dikembangkan mampu menyimpan data berupa laporan posko bencana.

6. Sebanyak $50.8 \%$ responden sangat mudah menggunakan fitur yang dikembangkan di dalam sistem.

\section{DAFTAR PUSTAKA}

Akevren, S. (2010). peraturan BNPB. (February), 210.

Beze Husmul Kamasiah, Mardiana. 2018 Pengembangan Sig Berbasis Web Pada Tutupan Hutan Kota Studi Kasus Kecamatan Samarinda Seberang Dan Palaran. Jurnal Digit Vol 6: 37-46.

Jogiyanto. (2017). Konsep Dasar Sistem Informasi. Konsep Dasar Sistem Informasi.

Nur, A. (2016). PENANGGULANGAN BANJIR PADA KOTA SAMARINDA. 151, $10-17$. https://doi.org/10.1145/3132847.313288 6

O'Brien, J. A., \& Marakas, G. M. (2012). Introduction to Information System. Paul Ducham, 66, 37-39.

Prahasta, E. (2002). Konsep -Konsep Dasar Sistem Informasi Geografis. Bandung: Informatika.

Roger, \& Aini, A. (2007). Sistem informasi geografis. (2010).

Supriyono, S., Guntar, D., Edwar, Zairin, \& Sugandi, W. (2018). Sosialisasi Potensi Bencana dan Sistem Informasi Geografi (SIG) Kebencanaan di Kabupaten Seluma. Jurnal Bagimu Negeri, 2(1), 59-68.

https://doi.org/10.26638/jbn.552.8651

Suryani, L. (2008). Panduan Laravel PHP Framework. IImu Teknologi Informasi, 5.

UU. (2007). undang-undang republik indonesia. Undang-Undang Republik Indonesia, вы12y(235), 245.

yakub. (2011). Diagram Arus Data. Pengantar Sistem Informasi, 2011(3), 1-18. Retrieved from en.wikipedia.org /wiki/Data_flow_diagram

Zamiati, Z. (2014). Pencegah Kebakaran Ditempat Kerja. 